\title{
Anti-CD45RA Monoclonal Antibody
}

National Cancer Institute

\section{Source}

National Cancer Institute. Anti-CD45RA Monoclonal Antibody. NCI Thesaurus. Code C158687.

Any monoclonal antibody that recognizes receptor-type tyrosine-protein phosphatase $C$ isoform CD45RA. 